\title{
POPULATION DYNAMICS OF ORIENTAL HORNET (Vespa orientalis L.) DURING ITS ACTIVITY SEASON IN THE APIARY THROUGHOUT THE DAY PERIODS
}

\author{
Dina $^{1^{*}}$ S. El-Boulok, El-Sherif ${ }^{2}$ M.E., Ali $^{2}$ M.A.M. and Mansour ${ }^{1}$ H.M.
}

1. Beekeeping Dept., Plant Protection Research Institute, Agric. Research Center, Giza, Egypt

2. Plant Protection Dept., Fac. of Agric., Ain Shams Univ., P.O.B 68, Hadayek Shoubra, 11241, Cairo, Egypt

\section{*Corresponding author: dinasabry1984@hotmail.com}

\section{ABSTRACT}

The current experiment was carried out in the Faculty of Agriculture, Ain Shams University, Shoubra El-Kheima, Qualubia governorate, during the oriental hornet active season extended from September $1^{\text {st }}$ until end of December $31^{\text {st }}, 2015$, to estimate the daily counts of the oriental hornet (Vespa orientalis L.) as well as its population dynamics during its active season. The experimental apiary composed of twenty four honeybee colonies, each contained seven frames covered with adult bees and four frames of them contained brood. The wasp's traps were used for capturing the wasps during the day. The data summarized that, the average means of wasps captured for tested months were 8.79, 21.99, 13.42 and 1.10 wasp/trap for September, October, November and December 2015, respectively. The highest population of oriental hornet captured by the traps was recorded during October month, followed by November and September; meanwhile the population captured during December was the lowest, with significant differences between them. For daily count, the mean average numbers of wasps captured by the traps were $10.20,17.55$ and 6.22 wasp/trap for the three periods $(9 \mathrm{am}-12 \mathrm{pm}$, $12 p m-3 p m$ and 3pm - 9am of next day), respectively. The highest numbers of wasps captured by the traps were recorded during the noon period (12pm - 3pm) followed by morning period (9am $12 \mathrm{pm})$, meanwhile the afternoon and evening period (3pm - 9am of next day) recorded the lowest numbers of wasps captured by the traps, with significant differences between all the tested periods.
\end{abstract}

Overall the highest numbers of oriental hornet captured by wasp's traps were recorded in October month during the noon period, 12pm - 3pm and averaged (33.15 wasp/trap), followed by November month during the same period 12pm - 3pm (20.50 wasp/trap).

Keywords: Honeybee; Oriental hornet; Vespa orientalis; Controlling; Wasps; Traps.

\section{INTRODUCTION}

Vespa orientalis L. is one of the most dangerous pests that attack honeybee colonies in some parts of the world and considered a measure pest for beekeeping (Abou-Shaara, 2017). The population dynamics of oriental hornet in honeybees apiaries were studied by many authors, there active season extending from June to October with a peak invasion during July and September while there highest activity was at the noon then in the morning and evening periods (Chhuneja et al 2008).

The number of wasps reached the maximum values in October followed by September and November, then the population of wasps dropped until disappeared at the end of December (Sharkawi, 1964, Sharma and Raj, 1988, Sihag, 1992, Shoreit, 1998, El-Sherif, 2003, Gomaa and Abd El-Wahab, 2006, Abd Al-Fattah and Ibrahim, 2009, Ibrahim, 2009 and Omran et al 2011).

The activity of oriental hornet was more in the morning and noon as compared with in the evening, adult wasps activity started at $10.00 \mathrm{~h}$ but 
ceased at $16.00 \mathrm{~h}$ during spring and autumn, with the highest activity at mid-day and the maximum number of wasps visited the apiaries during autumn as compared with summer and winter season (Thakur and Bagga, 2000 and Khater et al 2001).

Khater et al (2001) used sticky traps for recording the change in oriental hornet population seasonal activity. The number of wasp's workers comes out from the nest at the noon period more than the number of those comes out in the morning or evening period (Volynchik et al 2008).

\section{MATERIAL AND METHODS}

The current experiment was carried out in the Faculty of Agriculture, Ain Shams University's apiary, Shoubra El-Kheima, Qualubia governorate, during the oriental hornet active season extended from September $1^{\text {st }}$ until end of December, 2015, to estimate the daily counts of the oriental hornet (Vespa orientalis L.) as well as its population dynamics during its activity season.

The experimental apiary composed of twenty four honeybee colonies, each contained seven frames covered with adult bees and four frames of them contained brood.

Three wasp's traps were setting in the experimental apiary and the numbers of oriental hornet caught were estimated three daily periods; in the morning (9am - 12pm), noon (12pm - 3pm) and the last one were from (3pm until 9am of next day).

Sugar solution (1:1) was used in the traps to attract the wasps and the syrup was changed every three day intervals.

The temperature and relative humidity of weather were recorded daily in the study area during the experimental period.

Obtained data were statistically analyzed by using a randomized complete block design in factorial arrangement according to (Sndecor and Cocheran 1990). For separation between means, least significant difference at $5 \%$ probability was applied.

\section{RESULTS AND DESSCSSION}

The total and average number of oriental hornet (Vespa orientalis L.) caught by wasp's traps throughout the day (9am - 12pm, 12pm - 3pm and $3 p m$ until 9am of next day) during its activity in the experimental apiaries was estimated and recorded during September $1^{\text {st }}$ until end of December $31^{\text {st }}$, 2015.

Data illustrated in Fig. (1) showed the total and average numbers of oriental hornet caught during the period extended from September $1^{\text {st }}$ until September $27^{\text {th }}$. The total numbers of wasps caught were (204, 394 and 114 wasp/trap) with an average of $(7.56,14.59$ and 4.22 wasp/trap) in the three periods, respectively. There were significant differences between all the tested periods where the highest population of wasps caught was during the noon period(12pm - 3pm) followed by the morning period (9am - 12pm), while the afternoon and evening period (3pm - 9am of next day) recorded the lowest population of wasps caught in the traps.

The same trend was recorded in October month where the highest numbers of oriental hornet caught were in noon period, (12pm - 3pm) with average of 33.15 wasp/trap and the lowest numbers were during evening period (3pm - 9am of next day) with an average of 12.52 wasp/trap. Significant differences were found between all the tested periods during October $1^{\text {st }}$ until October $28^{\text {th }}$ Fig. (2).

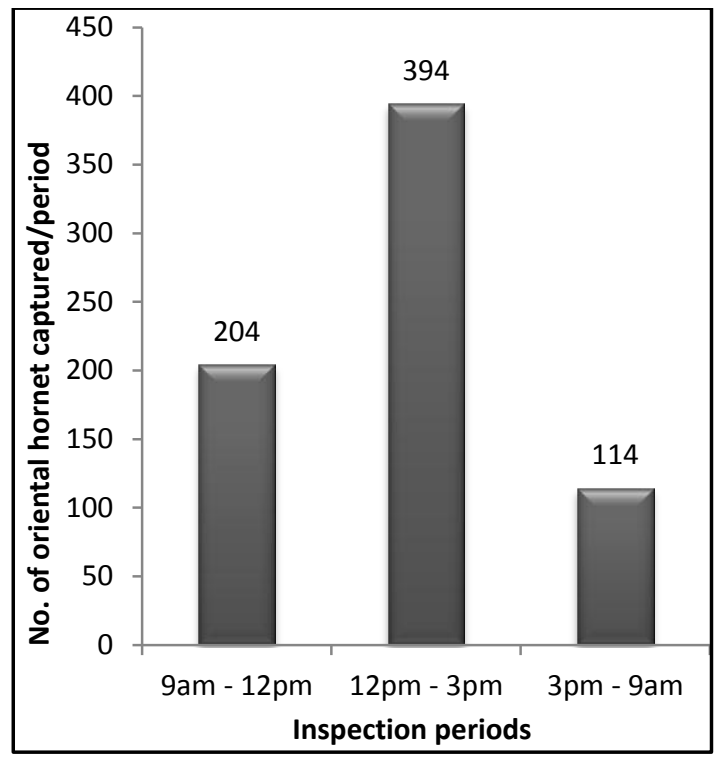

Fig. 1. Numbers of oriental hornet (V. orientalis L.) captured by the traps during September month, 2015 throughout the day. 

season in the apiary throughout the day periods

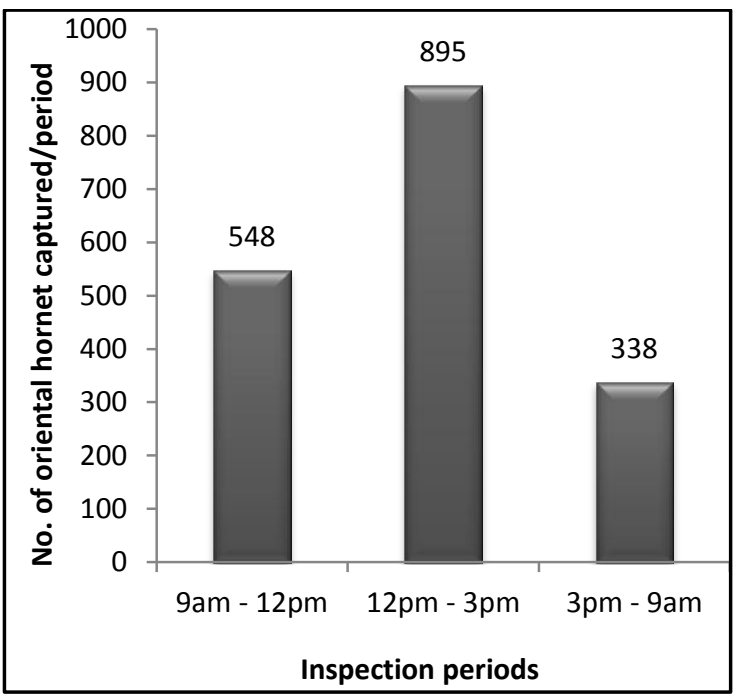

Fig. 2. Numbers of oriental hornet ( $V$. orientalis L.) captured by the traps during October month, 2015 throughout the day.

As showed in Fig. (3), the same trend was found, where the total and average numbers of wasps caught during November $4^{\text {th }}$ until $29^{\text {th }}, 2015$, were (289, 492 and 185 wasp/trap) with an average of $(12.04,20.50$ and 7.71 wasp/trap) for (9am - 12pm, 12pm - 3pm and 3pm until 9am of next day), respectively. Significant differences were found between all the tested periods, where the highest population of wasps in the traps was recorded in noon period (12pm - 3pm) and the lowest population was recorded in the last period $(3 \mathrm{pm}$ until 9am of next day).

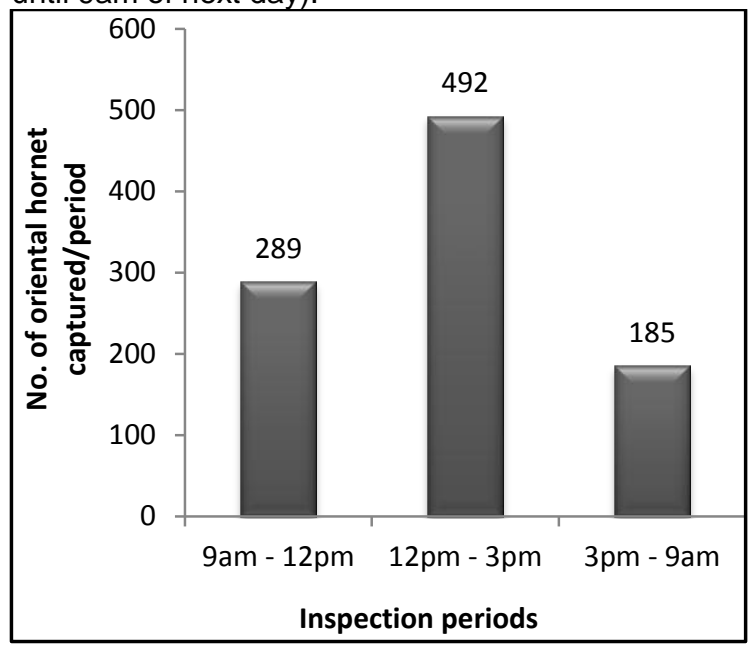

Fig. 3. Numbers of oriental hornet ( $V$. orientalis L.) captured by the traps during November month, 2015 throughout the day.
During December $2^{\text {nd }}$ until December $31^{\text {st }}$ the population of oriental wasps captured in the traps recorded the lowest numbers among the other tested months, where the total and the average of wasps captured were (24, 53 and 12 wasp/trap) with an average of $(0.89,1.96$ and 0.44 wasp/trap). No significant differences were found between the tested periods Fig. (4).

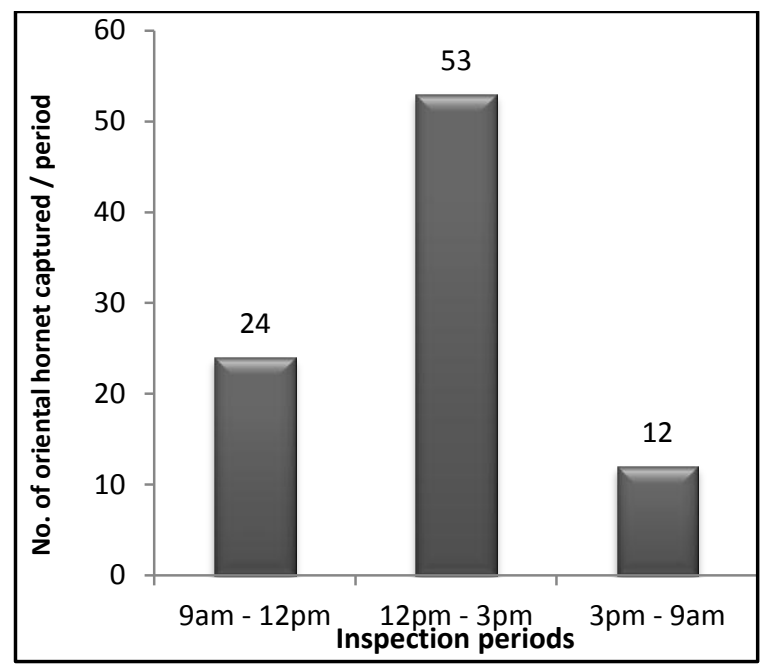

Fig. 4. Numbers of oriental hornet (V. orientalis L.) captured by the traps during December month, 2015 throughout the day.

Regardless the tested daily periods, the general means of tested months was $(8.79,21.99$, 13.42 and 1.10 wasp/trap) for September, October, November and December, 2015, respectively. The highest population of oriental hornet captured by the traps was recorded during October month, followed by those in November and September months, meanwhile the population captured during December month was the lowest, with significant differences between them.

Regardless the inspected month, the average number of wasps captured by the traps was (10.20, 17.55 and 6.22 wasp/trap) for the three periods (9am - 12pm, 12pm - 3pm and 3pm 9am of the next day), respectively. The highest number of wasps captured by the traps was recorded during the noon period (12pm $-3 p m)$ followed by morning period (9am - 12pm), meanwhile the afternoon and evening period (3pm 9am of next day) recorded the lowest number of wasps captured by the traps, with significant differences between all the tested periods. 
Overall the highest numbers of oriental hornet captured by wasp's traps were recorded in October month during the noon period, 12pm - 3pm with an average of 33.15 wasp/trap, followed by November month during the same period, 12pm - 3pm (20.50 wasp/trap).

The results in agreement with data obtained by (Sharkawi, 1964, Sharma and Raj, 1988, Sihag, 1992, Shoreit, 1998, Gomaa and Abd El-Wahab, 2006, Abd Al-Fattah and Ibrahim, 2009, Ibrahim, 2009 and Omran et al 2011), whom found that the population of oriental hornet reached the highest value in October followed by September and November and the data obtained by (Thakur and Bagga, 2000 and Khater et al 2001), whom recorded that, the activity of oriental hornet were more in the morning and noon periods as compared with in the evening, and added that adult wasps activity started at $10.00 \mathrm{~h}$ but ceased at $16.00 \mathrm{~h}$ during spring and autumn, with the highest activity at midday and the maximum number of wasps visited the apiaries during autumn as compared with summer and winter seasons.

\section{REFERENCES}

Abd Al-Fattah, M.A. and Ibrahim, Y.Y. 2009. The serious of dangerous insect predator (Vespa orientalis L.) on honeybee colonies in Giza governorate. $4^{\text {th }}$ Conference on Recent Technologies in Agriculture. pp. 58-65.

Abou-Shaara, H. 2017. Morphological aharacterization and wing description of Vespa orientalis queens. Biotechnology in Animal Husbandry. 33(2), 251-259.

Chhuneja, P.K., Singh, J., Blossom and Gatoria, G.S. 2008. Population density of Vespa orientalis Linnaeus attacking Apis mellifera Linnaeus colonies in Punjab. J. of Insect Science (Ludhiana). 21(2), 161-167.

El-Sherif, M.E. 2003. Seasonal fluctuation of oriental hornet, Vespa orientalis, its trapping efficiency and honey bee activities. J. Agric. Sci. Mansoura Univ. 28(4), 3133-3147.

Gomaa, A.M. and Abd El-Wahab, T.E. 2006. Seasonal abundance and the efficiency of yeast liquid culture (Candida tropicalis) as bait for capturing the oriental wasps (Vespa orientalis L.) under egyptian environment. J. of Applied Sciences Research. 2(11), 1042-1046.
Ibrahim, Y.Y.M. 2009. Evaluation of defensive behavior of honeybee (Apis mellifera L.) colonies against the attack of oriental hornet (Vespa orientalis L.). Ph.D. in Agricultural Sciences, of Economic Entomology and pesticides Dept., Fac. of Agric., Cairo Univ., Giza, Egypt. 271 p.

Khater, A.M., Ebadah, I.M.A. and Yousif-Khalil, S.I. 2001. The seasonal activity of oriental wasp, Vespa orientalis L. populations attacking honeybee colonies. Arab Univ. J. of Agricultural Sciences. 9(1), 447-455.

Omran, N.S.M., Hussein, M.H., Khodairy, M.M. and Awad, A.M. 2011. Predators of honeybee and its impact on activities of honeybee colonies under conditions of south valley, Egypt. Research Journal of Agriculture and Biological Sciences. 7(1), 79-88.

Sharkawi, S.G. 1964. The morphological, biological, ecological and Control of $V$. orientalis, FAB. (Hymenoptera, Vespidae). M.Sc. of Science in Agriculture (Agriculture Zoology Apiculture) Bee Dept., Fac. of Agric., Cairo Univ., Giza, Egypt. 208 p.

Sharma, O.P. and Raj, D. 1988. Ecological studies on predatory wasps attacking italian honeybee, Apis mellifera L. in kangra shivaliks. Indian J. of Ecology. 15(2), 168-171.

Shoreit, M.N. 1998. Field observations on the seasonal abundance and control of the oriental hornet, Vespa orientalis L. attacking honeybee colonies in Egypt. Assiut Journal of Agricultural Sciences. 29(1), 15-21.

Sihag, R.C. 1992. The yellow banded brown wasp Vespa orientalis L. 1. A predator and colony robber of honey bee (Apis mellifera L.) in Haryana (India). Korean J. of Apiculture. 7(1), 32-34.

Sndecor, G.W. and Cocheran, W.G. 1990. Statistical Methods, $7^{\text {th }}$ Ed., lowa State University Press, Ames, lowa, USA. 507 p.

Thakur, S.S. and Bagga, V.K. 2000. Foraging ecology of Vespa auraria Smith under mid-hill conditions of Himachal Pradesh, India. Pest Management and Economic Zoology. 8(2), 123-127.

Volynchik, S., Plotkin, M., Bergman, D.J. and Ishay, J.S. 2008. Hornet flight activity and its correlation with UVB radiation, temperature and relative humidity. Photochemistry and Photobiology. 84(1), 81-85. 


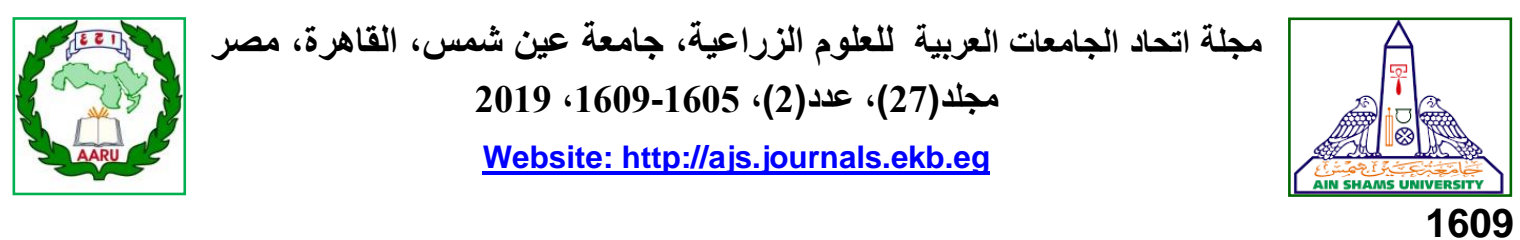

ديناميكية التعاد للابور الثرقي . Vespa orientalis L أثناء موسم نثاطه في المندل

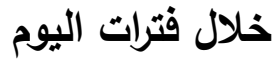

[131]

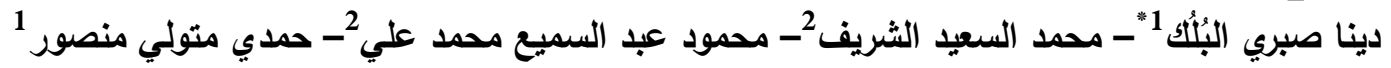

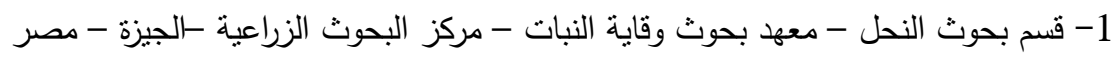
2- قسم وقاية النبات - كلية الزراعة - جامعة عين شمس - صندوق بريد 68 - حدائق شبرا 11241 - القاهرة - مصر

"Corresponding author: dinasabry1984@hotmail.com

Accepted 13 February, 2019

كما كان متوسط التعداد اليومي للابابير التي نت جمعها

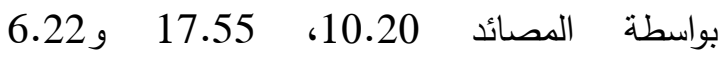
دبور/مصيدة للفترات الثثلاثة (من التاسعة صباحاً حتى الثانية عشرة ظهراً ومن الثانية عشرة ظهراً حتى الثناء الثالثة

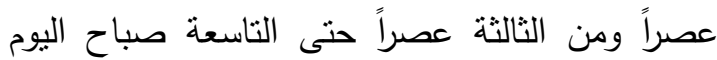

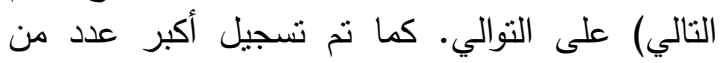
الدبابير التي تم جمعها بواسطة المصائد خلال الفيال الفترة

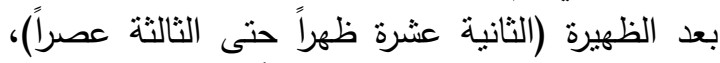
يليها فترة الصباح (التاسعة صباحاً حتى الثانية عشرة طنية ظهراً)، في حين سجلت فترة المساء (من الثاء الثالثة عصراً

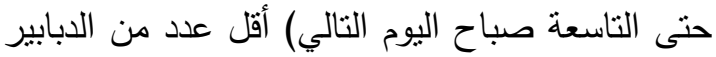

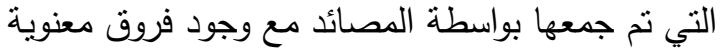

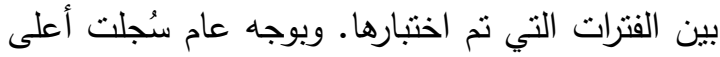
أعداد للابور الثرقي التي تم جمعه بواسطة مصائد الدبابير في شهر أكتوبر خلال فترة الظهير الظهيرة (الثانية

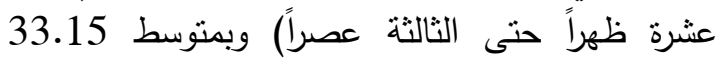
دبور/مصيدة، يليها شهر نوفمبر خلال نفس الفترة وبمتوسط 20.50 دبور /مصيدة

الكلمات الدالة: نحل العسل، الدبور الثرقي، المكافحة،

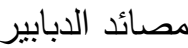

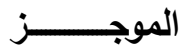

أجريت التجربة في منحل كلية الزراعة، جامعة عين شمس، شبرا الخيمة، محافظة القليوبية، أثناء موسم نشاط الدبور الثرقي خلال الفترة من بداية سبتمبر حتى نهاية ديسمبر 2015، لتقدير الأعداد اليومية للابور الثرقي (Vespa orientalis L.)

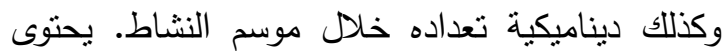
منحل التجربة على أربعة وعشرين طائفة نحل كل منها

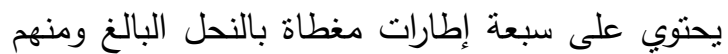

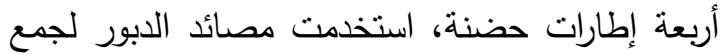

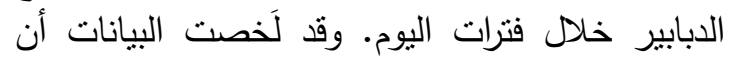

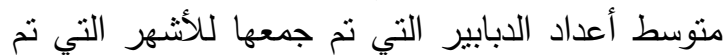

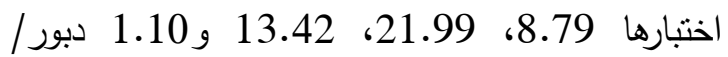
مصيدة لشهر سبتمبر وأكتوبر ونوفمبر وديسمبر وانسبر 2015، على التوالي. كما أثنارت النتائج أن أعلى ونى تعداد للابابير التي نم جمعها بواسطة المصائد خلال

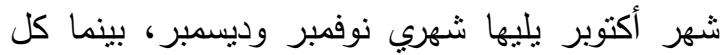

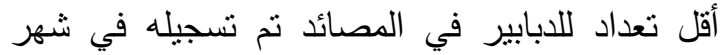
ديسمبر مع وجود فروق معنوية بين الأشهر المختبرة. 